\title{
FOOD INSECURITY IN MALI: EXPLORING THE ROLE OF THE MORAL
} ECONOMY

\section{Alayne Adams}

\section{INTRODUCTION}

Following the work of Sen (1981), famine analysis has moved beyond the question of food availability decline, to the problem of entitlement failure. ${ }^{1}$ The famine process is characterized as a collapse in an individual's ability to legally command food through the disposal of productive resources or endowments (land, labour, assets) and exchange in the form of trade and production. Overlooked in this analysis of individual entitlement failure vis à vis food in the market economy, is the parallel collapse of social structures which sustain important non-market sources of food in much of the developing world (Firth 1959; Laughlin 1974; Dirks 1980).

A complex system of social strategies and institutions which work to minimize the risk of food insecurity has been documented in pre-capitalist society (Evans-Prichard 1940; Scott 1976; Posner 1980; Platteau 1991; Fafchamps 1992). Based on kinship, friendship and patronage, this 'moral economy' mediates the flow of non-market claims and transfers in a variety of forms ranging from cereal gifts and livestock loans, to migrant remittances, and labour exchange. The right to make claims on others, and the obligation to transfer a good or service, is embedded in the social and moral fabric of the rural community (Mauss 1959, Scott 1976). These principles are sustained in large part by the long-term self-interest of households in search of mutual insurance against livelihood insecurity (Laughlin 1974; Posner 1980; Platteau 1991).

The contribution of non-market transfers to food security in the contemporary context has been largely dismissed. With the expansion of market exchange, population growth and the rise of the modern state, it is argued that claims and transfers are atavistic vestiges of a 'merrie' moral economy of times past (Polanyi 1944, Raynault 1975, Scott 1976, Watts 1984). As a result, scant attention has been paid to the role of non-market transfers in preventing famine, nor the devastating impact of famine-related disloca- tion, disease and hunger on the social practices and institutions which sustain these flows.

This article examines the contribution of non-market transfers to the food security of Bambara agriculturists in central Mali. Analysis is based on fieldwork which involved a cross-sectional survey of 7 villages (150 households) during the harvest seasons of 1988 and 1989, and an 18 month longitudinal study of 33 households in the village of Sèbèkoro (Adams 1992). After considering the nature of food insecurity in Mali, the social and economic networks which have developed to cope with this perennial problem are described. Highlighting the importance of social investment and exchange in maintaining subsistence security, the article goes on to explore the nature and material importance of non-market transfers in coping with food insecurity, including the characteristics of donor, recipient and excluded households.

\section{FOOD INSECURITY IN MALI}

Documented in the early anthropological studies of the Tallensi in Ghana (Fortes and Fortes 1936), and the French Colonial Sudan (Pales et al. 1954), the problem of food insecurity continues to persist in contemporary West Africa. Given low levels of technology development and marked variations in the adequacy of rainfall and its distribution over the cultivation season, agricultural yields and subsequent food security remain in continual peril. Since independence (1960), Mali has experienced frequent food crises, most notably the famine of 1968-73, and the droughts of 1983-84 and 1988. In addition to these periods of chronic or famine-scale food shortage, seasonal food insecurity is also widespread in the region. This period of transitory scarcity tends to occur in the rainy season prior to the harvest when cereal supplies are constrained, and energy needs related to agricultural work reach their peak (Chambers et al. 1981).

\footnotetext{
1 The author would like to acknowledge the International Development Research Centre (IDRC) for supporting this research.
}

Special thanks are extended to Salif Sow and Timothy Evans for their insight and editorial advice. 
Straddling Sudanic and Sahelian climatic zones, the study region receives between 600 and $800 \mathrm{~mm}$ of rainfall per annum concentrated in a single rainy season from July to October. Dryland millet production is the primary subsistence activity of Bambara agriculturists, supplemented by the proceeds from groundnut cash crops, crafts, petty commerce, and small-scale animal husbandry. Due to inadequate rainfall in 1988, only 11 per cent of households surveyed harvested enough millet to supply domestic consumption throughout the year. Among those households having to procure cereal through other means, 53 per cent were food insecure as evidenced by the need to ration and substitute wild foods in place of cereal. Improved, albeit late rainfall in 1989 enabled 43 per cent of households to meet annual cereal needs through domestic production, while only 25 per cent of production deficit households were food insecure.

In view of this precarious environment, survival depends largely on the household's ability to minimize risk. A range of strategies is summoned to enhance subsistence security, and to cope with food crises when they occur. Cropping strategies such as early ripening varieties, field dispersion, intercropping and staggered planting help spread production risks in time and space (Norman 1977; Richards 1985), while market gardening, craft production, migration, and livestock investment permit the accumulation of assets to purchase food in times of need (Lewis 1979, Fulton and Toulmin 1982). Of concern in this article is the array of non-market strategies and social institutions such as collective labourgroups, communal fields, village cerealbanks, and kinship and dyadic exchange relationships; all of which provide a form of welfare or subsistence guarantee to participant households.

\section{SOCIAL AND ECONOMIC NETWORKS}

At the centre of Bambara social and economic organisation is the household. Figure 1 illustrates the networks which the household constructs in pursuit of subsistence security. Through exchange and social investment, it attempts to spread risk into ever widening orbits ranging from village kin, to urban migrants, market and state.

2 The trend toward the breaking up of large kinship-based production units was noted as early as 1934 by French colonial anthropologists (Labouret 1934). The growing individualization of production caused by increasing labour migration and individual incomes earned
Figure 1: Social and Economic Networks of Agricultural Households in Mali

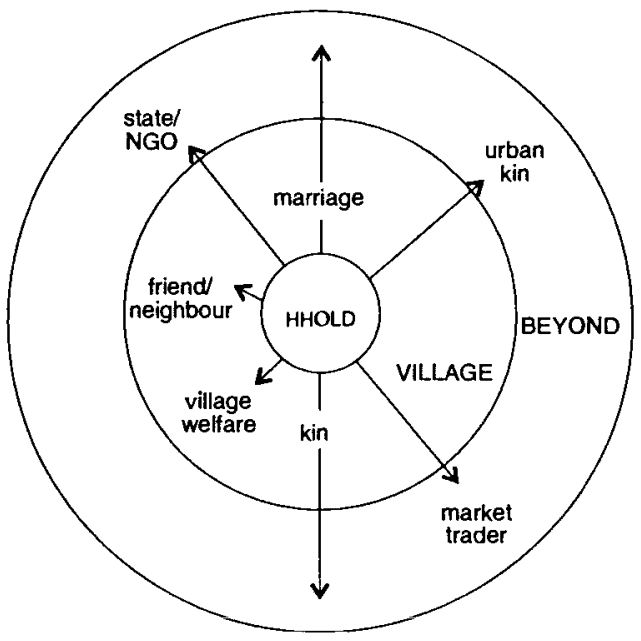

\subsection{The household}

The Bambara household is a dynamic entity comprised of individuals who farm a common field and who have rights to consume grain from a common granary (Meillasoux 1981). Subject to continual variations in rainfall, productive capacity, and consumption requirements, the typical household experiences periods of food deficit and surplus throughout its lifecycle (Fortes 1949; Goody 1958; White 1980). It is the duty of the household's most senior male member to control land-use rights, compoundlevel goods and the production and reproduction of household labour in the interests of collective subsistence. While household members have concomitant rights and obligations regarding collective production, gender and generational segments of the household may have social and economic interests independent, or indeed opposed, to those of the patriarch. Negotiation between collective and individual interests is necessary if a large and cohesive labour force is to be maintained. ${ }^{2}$

\subsection{The village}

The Bambara village is comprised of three main groups distinguished by the degree to which they

through cash-crop production and market activity are factors perceived to weaken the traditional strength of the household head and to promote the fissioning of the household into smaller nuclear units (Paques 1954; Brasseur 1961; Klaus 1976). 
are integrated into social and economic networks of exchange. In the first group are long-established households with patrilineal ties which date back to the origins of the village. The village chief generally represents the most senior member of the founding patrilineage. ${ }^{3}$ Within these established lineage groups, mutual aid is considered obligatory; more wealthy households providing an informal welfare guarantee to poorer kin. In Sèbèkoro, the village chief supported the near destitute households of a blind son-in-law and an uncle disabled by leprosy.

The second group includes non-lineage households either recently established in the village or ostracized from lineage networks due to long-standing family quarrels. With less developed kinship ties and minimal obligations to others, non-lineagehouseholds have greater latitude in productive decisionmaking, but less access to social and economic support in the event of crisis. For this reason, nonlineage groups may try to access social networks within the village through marriage, while at the same time, maintain some of their older alliances through child fostering and seasonal visits to their villages of origin." Relationships between neighbouring non-lineage households are affirmed through labour exchange, and small gifts of food, tobacco and cola nut.

Constituting the third group are the households of blacksmiths, bards, carvers and leather workers whose special skills afford them a privileged place in Bambara society (McNaughton 1988). Owning the rights to arcane, spiritual and technological practices, they offer these services in return for tributes of food and cereal.

Cross-cutting the hierarchical household and lineage stratification of the village are associations which work to create a sense of equality and community within the village as a whole (Lewis 1979). Particularly common are labour groups based on the 'ageset' system. The Ton or cibò is one such obligatory work group comprised of young men aged 13 to 35 . Although all households with male members in this age range are expected to participate, it is far easier for non-lineage households to opt out of communal labour obligations than for those with strong kinship affiliations. Thecibò provides paid labour during the

3 With the counsel of elders, the village chief administers and distributes land to community members, sets the main stages of the agricultural calendar, acts as a representa tive to regional govemment and arbitrates in cases of dispute (Klaus 1976: 57) peak agricultural season on designated days of the week often chosen in coordination with surrounding villages. The proceeds earned by communal work groups may be used to receive religious and official visitors or may constitute a fund from which villagers can borrow if, for example, tax payments are required before the sale of cash crops.

Other examples of cooperative institutions are associations of villagers who cultivate a communal field, the produce of which is used as a security stock of seed and cereal. In the event of food shortage, cereal credit may be obtained and repaid after the harvest. Six of the seven villages studied cultivated a communal field of this kind.

\subsection{Beyond the village}

Extending beyond the village are orbits of exchange which includeneighbouring villages, urban migrants, market and state. Through marriage, social ties with surrounding villages are strengthened and subsistence networks diversified. Marriage is a collective affair in Bambara society, traditionally arranged between the parents of exogamous lineages. In Sèbèkoro, 24 per cent of married women came from households within the village itself, 39 per cent originated from surrounding villages within a $5 \mathrm{~km}$ radius, while the remainder issued from more distant regions.

Maintaining and developing social and economic networks through marriage is a matter of great importance even if it results in lost production in the immediate term (Fulton and Toulmin 1982). For example, during the process of bride price payment, a prospective husband may be obliged to gather together members of his 'age-set' and provide free labour to future in-laws even if this request coincides with the peak agricultural season. After marriage, these networks are maintained through visits of married women to their natal villages, and through exchanges of gifts and services. In the long-term, networks established through marriage act as insurance against highly localized differences in farming fortunes. Many farmers noted how flows of cereal along the 'marriage road' during periods of shortage are increasingly important as intra-village lineage networks weaken through household fission and migration.

\footnotetext{
- The practice of child-fostering is widespread in West Africa (Bledsoe et al. 1988). In the village of Sebekoro, 10 childless or elderly women were bequeathed children of matrilineal kin.
} 
Of similar economic importance are networks between urban migrants and their households of origin. Although it is difficult for the household to make and enforce claims on distant migrant kin, periodic remittances are critical sources of cash income that may be mobilized during shortage.

With the establishment of regional and local markets for cash crops, local traders have become a vital source of cash, cereal and credit for Bambara households. At the same time as traders speculate and exploit demand/supply discrepancies for a profit (Hill 1972), a variety of patron-client arrangements are apparent between farmer and trader; loyal clients receiving preferred access to credit, or in some cases, temporary employment in exchange for cereal. The recent liberalization of cereals trade from a state controlled marketing system has further entrenched relations between farmer and trader (Staatz et al. 1989). By contrast, state involvement in the study region is limited. State-level infrastructure and extension services are underfunded and overextended, while regional cereal food security stocks are only sporadically reinforced and distributed (Bulletin SAP 1987-90). NGO assistance is similarly limited in scope and coverage.

\section{THE PURSUIT OF FOOD SECURITY THROUGH NON-MARKET TRANSFERS}

Negotiating the networks described above, rural agriculturists forge and reinforce obligations of debt and favour in pursuit of subsistence security. Nonmarket transfers may act to prevent the occurrence of food insecurity through direct access to food such as cereal gifts and meal sharing. Alternatively, access to food may be indirectly transferred through labour exchange, loans of agricultural inputs which serve to enhance production, or through capital transfers, the proceeds of which can be used to obtain food. This section distinguishes four categories of transfers: ritual homage and alms, gifts, exchange and credit. After Sahlins's (1965) concept of reciprocity in 'primitive society', these four categories of transfers can be viewed as a 'continuum of exchange' distinguished in terms of the 'degree of tolerance for material imbalance indicated by the time allowed to reciprocate' (Sahlins 1965: 146-48). The following analysis considers the normative rules and obligations surrounding each category of transfer, and the quantity and frequency of the particular entities being exchanged.

\subsection{Homage and almsgiving}

In the Bambara village, ritual transfers of homage and alms are the moral duty of Animist and Muslim believers alike. Indeed, traditional Animist practices such as homage paid to ancestral priests for good fortune in farming, coexist with or have even transformed Islamic almsgiving and charity to the destitute (zakkat). ${ }^{5}$ Offerings to cult priests are provided to Muslim clerics instead, or to elderly or infirm relatives thereby fulfilling obligations to kin and Allah simultaneously (Trimingham 1959: 189).

Table 1: Cereal Outflows in Sèbèkoro $(\mathrm{kg} / \mathrm{hold})$

$\mathrm{n}=33$ households

\section{TYPE}

cereal sale

salaries

consumption

debt repayment

alms given

gifts given

credit given

TOTAL

$\begin{array}{cc}\text { ANNUAL } & \text { OUTFLOWS } \\ 166 & (255) \\ 162 & (197) \\ 2373 & (1535) \\ 42 & (92) \\ & \\ 248 & (251) \\ 255 & (364) \\ 9 & (28)\end{array}$

3253 mean (sd)

PER CENT PROD*
7
6
93
2

10
10
.3

$\begin{array}{llll}1336 & 994 & 923\end{array}$

* Domestic production is supplemented by purchases, gifts and credit, hence per cent figures do not add up to 100.

\footnotetext{
5 Islamic law requires that 10 per cent of annual production or income, be distributed among the old, the infirm and the destitute.
} 
Homage and almsgiving presume that the household has an economic surplus over subsistence needs to distribute (Trimingham 1959: 184). While data from Sèbèkoro indicate a strong positive correlation between production and almsgiving ( $r=+0.79$ $\mathrm{p}<0.001$ ), many production deficit households disbursed a large percentage of their scanty harvest as alms despite obvious implications for their food security.

Table 1 summarizes mean household cereal outflows for the village of Sèbèkoro. Homage and almsgiving constitute almost 10 per cent of mean agricultural production, most of which is disbursed as zakkat following the harvest. The most frequent recipients are roving Muslim clerics (26 per cent), the destitute (17 per cent), representatives of ancestral spirits (14 per cent) and the village blacksmith ( 7 per cent).

\subsection{The gift}

The second category of non-market transfers is the gift; a symbolic or tangible exchange of goods or services that carries with it some obligation to reciprocate. Gift exchange provides an important means of minimizing climatic and demographic risk as household production and consumption needs vary over time. Gift-giving cultivates and converts social resources into a system of mutual insurance so that: '...(s)he who is in need today receives help from (s)he who may be in need tomorrow' (Evans-Pritchard 1940: 85). Reciprocation need not be immediate, nor must there be any necessary equivalence to the initial gift (Sahlins 1965: 160)

Although gift behaviour is more likely to be found in communities where the kinship idiom prevails, in the modern Bambara village gift exchange is also used to assist and validate strong informal ties of cooperation and trust between individuals and households unrelated by kinship or marriage. Given the spacio-temporal variability of cropping fortunes in this Sudano-Sahelian region, exchange relationships with households from surrounding villages are also strategic. Exogamous marriage alliances facilitate a risk-spreading diversification of social and economic networks beyond the village. For non-lineage households, marriage ties within the village or nearby vicinity provide an expedient way of creating local kinship links which might be relied upon in case of crisis.
As shown in Table 1, 10 per cent of annual millet production in Sèbèkoro is disbursed as cereal gifts to kin (22 per cent) and other household visitors (41 per cent). During the dry season, it is common for married women to return to their natal villages for several months at a time. Receiving food and lodging for the duration of their stay, they are entitled to substantial gifts of cereal on their departure. Indeed, whether kin or non-kin, Bambara tradition demands that all visitors receive gifts of cereal and other gestures of respect. Supporting Toulmin's observations near Segu (Toulmin 1986: 65), an increase in the frequency of visits from distant kin, praise-singers and traveling musicians was noted in the study region following the plentiful harvest of 1989.

Money gifts from migrant kin also represent an important yet unpredictable non-market transfer from which food may be obtained. Over 40 per cent of households in the region have at least 1 member absent on long-term migration. In Sèbèkoro alone, a total of 10 households received money gifts for cereal purchase during the rainy season months of June and July: in 7 cases these remittances came from migrant sons, in 2 cases from other kin. The mean value of these gifts was 24,000 FCFA, or the equivalent of 480 kilograms of millet at rainy season prices.

Sustaining these more formal gifts of money and cereal is an under-current of smaller daily transactions of condiments, meals, tobacco and cola-nut undertaken mainly by women. In Sèbèkoro, 29 per cent of these transactions involved meal giving, followed by gifts of cola-nut or tobacco (18 per cent) and condiments (18 per cent). Most of these gifts were directed to friends and neighbours ( 43 per cent) and post-harvest visitors (19 per cent).

Indirect forms of food assistance may also be provided through gifts of labour and/or agricultural equipment which benefit crop production. Table 2 outlines the different types of non-domestic labour in Sèbèkoro and the percentage of 'out-labour' days devoted to each. Of interest are the first three categories of labour exchange which fall under gift transfers: kin, in-law and charitable labour. A similar 'obligatory' ethic surrounds each: labour required by kin behind in their cropping schedule, the provision of 'age-set' labour to the households of prospective fathers-in-law, and the supply of charitable labour to respected or destitute households or to those who have experienced misfortune such as accident, crop damage, or the death or illness of 
Table 2: Non-domestic Labour Exchange in Sèbèkoro: per cent out-labour days per catagory

$\mathrm{n}=33$ households

$\begin{array}{lcccr}\text { Category } & \begin{array}{c}\text { Overall } \\ \mathrm{n}=1452\end{array} & \begin{array}{l}\text { Harvest } \\ \mathrm{n}=291\end{array} & \begin{array}{c}\text { Dry } \\ \mathrm{n}=325\end{array} & \begin{array}{r}\text { Rainy } \\ \mathrm{n}=836\end{array} \\ \begin{array}{l}\text { kin labour } \\ \text { in-law labour } \\ \text { charitable labour }\end{array} & 7 & 3 & 11 & 6 \\ \text { cibò labour } & 2 & - & 1 & 4 \\ \text { community labour } & 4 & 5 & 1 & 5 \\ \text { labour exchange } & 28 & - & 25 & 38 \\ \text { labour sale } & 22 & 2 & 20 & 29 \\ & 25 & 73 & 31 & 8 \\ \text { Total } & 12 & 17 & 11 & 10 \\ & 100 & 100 & 100 & 100\end{array}$

draught animals. No formal or immediate payment is required, however, there is an implicit promise of reciprocal help in the future (Platteau 1991: 142). Together, 'gift labour' accounts for 13 per cent of total out-labour days in Sèbèkoro.

A significant positive correlation between household gift-giving, domestic cereal production and wealth suggests that generosity may be a function of a household's productive strength $(r=+0.51 p<0.01)$. However, the absence of a significant negative correlation between gift-receiving and agricultural production suggests that the food insecure in Sèbèkoro may not be the major recipients of that generosity $(\mathrm{r}=-0.36)$.

\subsection{Exchange}

Like Sahlins's notion of 'balanced reciprocity', exchange transfers involve the immediate return of goods and services rendered (Sahlins 1965: 146). In the Bambara village, exchange largely consists of labour or capital transfers which act 'indirectly' to enhance the food security of participant households. Falling into this category are labour sharing arrangements such as threshing teams which move between the fields of participant households to accomplish time intensive tasks more quickly. In the dry season, kin or neighbouring households form similar work groups for the purpose of house repair. Labour exchange of this kind accounts for 25 per cent of nondomestic labour, most of which occurs in the harvest and dry seasons. Cibò labour, which accounts for a further 28 per cent of non-domestic labour days, embodies both exchange and market principles. Although participation entitles households to receive cibò labour, a standard charge is applied. In Sèbèkoro, a half day of cibò labour may be requested on the condition that a 2500 FCFA fee be paid after the harvest. For poor households, this fee is often prohibitive, as is the obligation to feed cibò labourers when cereal is scarce.

Individual labour contracts also mediate important non-market transfers of cereal. These contracts are mainly arranged between poor households short of cereal and more affluent farmers in the vicinity needing labour during the rainy season. During the severe food shortage of 1988, 42 per cent of such contracts involved the exchange of labour for cereal, while in the remainder of cases a money wage was used to purchase cereal on the market (Figure 2).

Capital transfers such as the loan of animals in exchange for ploughing and other agricultural services, also occur between kin and neighbour. One such arrangement was made between a blind household head, his leper wife and three children, and wealthy kin. The labour of his eldest son was loaned to affluent relatives for the duration of the rainy season on the condition that they cultivate a field of millet on his behalf. In another instance, a household agreed to tend the field of a destitute female-headed household in exchange for the use of her plough. 
Figure 2: Food Shortage Days Supplied by Market and Non-market Strategies in 1988

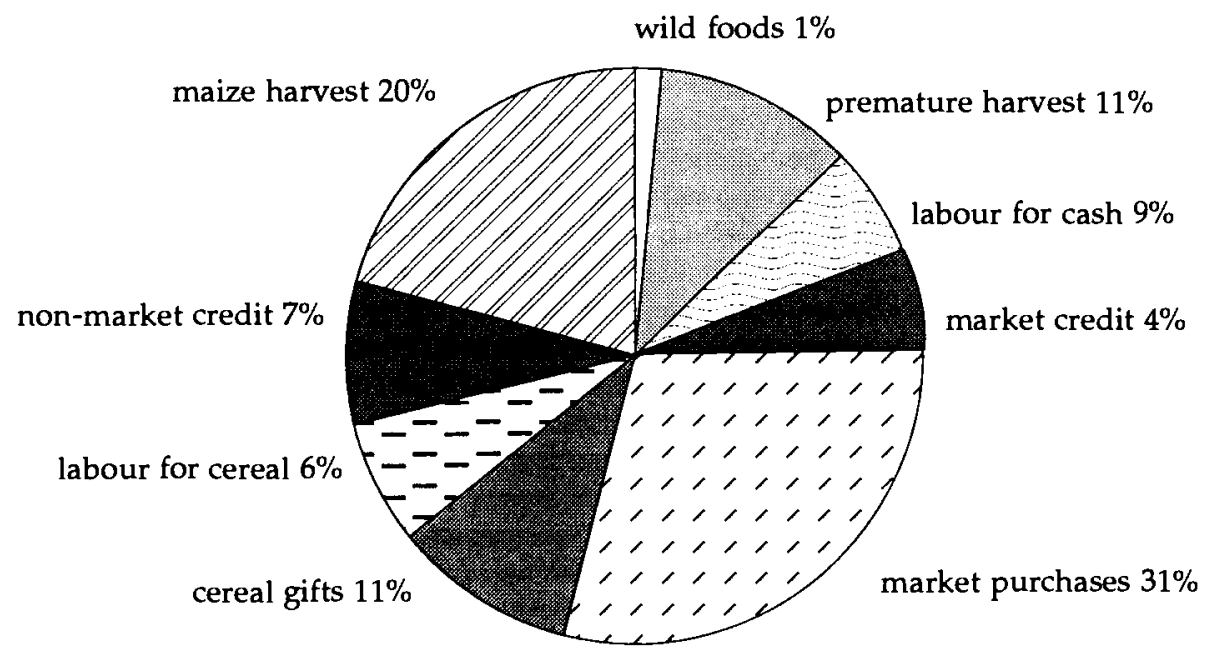

$\mathrm{n}=\mathbf{1 4 3 9 4}$ food shortage days, 7 villages in central Mali

Inter-ethnic forms of exchange are also common in the study region. During seasonal migrations, transhumant Fulbe exchange milk and labour for cereal cultivated by the Bambara. Similar exchange relationships are established beween Moor families who migrate southward from the Sahel at the beginning of the harvest season, and establish temporary residence on the compound fields of Bambara households: the host household benefits from soils wellmanured by Moor livestock, while the Moors are given permission to gather remaining millet at harvest threshing sites.

\subsection{Credit}

Credit transfers demand a stricter schedule of repayment than the other categories of non-market exchange. Depending on the degree of intimacy between partners, interest may or may not be required in the transaction. Interest-free credit is generally confined to transfers from village-level cereal banks or partners of relatively close social span. Negotiated outside of the market, a tacit promise is made to repay the debt by a certain date, and to extend similar aid if needed. The interest foregone by the credit giver can be considered the equivalent of a risk premium to insure against future contingencies (Platteau 1991: 151). The threat of social sanctions and public humiliation is usually sufficient to make the potential free-rider comply, as is the risk of losing credit opportunities in the future. The majority of cereal loans reported during food shortage periods in 1988 and 1989 are of this non-market variety contracted with friends, neighbours, kin and village cereal banks.

\section{NON-MARKET TRANSFERS DURING FOOD CRISES}

While many non-market strategies and institutions work to reduce the risk of food insecurity, are they effective in the context of widespread food crises? It is frequently argued in the literature that non-market transfers are irrelevant vestiges of a waning moral economy, and of little significance relative to market-oriented strategies widely employed to overcome food insecurity (Watts 1984). Study findings confirm that indeed non-market transfers represent only one of a diversity of coping strategies used to breach seasonal food deficits. Figure 2 expresses the relative importance of different food sources in terms of the percentage of food shortage days they furnish. Together, non-market cereal transfers comprised of gifts, non-market credit and labour-for-cereal exchange supply almost 25 per cent of food shortage days in 1988 .

However, if the household sample is stratified according to whether or not non-market transfers were received, a different impression emerges. Among 
those households receiving non-market transfers, cereal gifts or non-market credit supplied over 50 per cent of food shortage days in 1988. Moreover, a significant correlation between transfers received in 1988 and 1989 suggests that they remain important strategies from one year to the next $(r=0.51 p<0.01)$.

Another literature suggests a deterioration in patterns of socio-economic solidarity and non-market food transfers with increasing food insecurity (Firth 1959; Laughlin 1974; Turnbull 1982). As household priorities shift from a concern with long-term solidarity and mutual insurance to the problem of immediate survival, a decrease in the quantity and frequency of exchange is expected. However, when comparing cross-sectional data from two food shortage seasons of contrasting severity, an opposite trend is apparent. During the agricultural season of 1988 when food insecurity was widespread, 27 per cent of households received food gifts compared to 13 per cent during the mild shortage of 1989 . The quantity of cereal transfers also appears greater in 1988: 16 per cent of the household sample received net cereal gifts surpassing $20 \mathrm{~kg} / \mathrm{cu}$ in 1988 , compared to 7 per cent in 1989. Similar patterns were observed for interest-free credit transactions in both years.

Contrary to the view that food insecurity is incompatible with reciprocity, data suggest that moderate scarcity can engender greater non-market exchange. In this respect, they support a model proposed by Dirks (1980) which identifies three phases of social and economic behaviour as food insecurity intensifies. In the 'alarm phase', or the early stages of shortage, an intensification of social and economic activity is expected. Reciprocity and assistance increase and productive alternatives are explored in the effort to supplement insufficient food stores. With the 'resistance phase', 'social ties begin to erode;...conservative measures are introduced that are antithetical to widespread generosity and broadbased group action' (Dirks 1980: 28). Sharing networks become increasing restricted to close kin and economic strategies increasingly short-term. Cooperative strategies are further eroded as deprivation reaches the 'exhaustion phase' (Dirks 1980). Although the intensification of non-market exchange documented in 1988 is reminiscent of Dirks' alarm phase, a concomitant tendency to confine cereal transfers to closer kin suggest the beginnings of 'resistance'. Although food insecurity did not reach the 'exhaustion phase' in the period of study, many households recalled the devastating impact of drought periods in 1968-73 and 1983-84. In worst cases, mounting tensions between gender, generation and kin provoked the disintegration of household and village-level organisation.

\section{WHO GIVES AND WHO RECEIVES: EQUITY OR DISPARITY?}

Field data suggest that some households havegreater access to networks of non-market exchange. Attempts to identify their social, economic and demographic characteristics using logistic regression yields a model which combines household size, wealth, proximity of kin, and household age to successfully predict 65 per cent of production deficit households receiving or not receiving food transfers. From this analysis and other qualitative observations, general typologies which describe donor, recipient and excluded households are identified:

1 Donor households tend to be large households self-sufficient in cereal production and well-established in village lineage networks.

2 Recipient households tend to be poorer, production insufficient households within lineage networks which have slumped into poverty through bad luck (ill-health, disability, crop damage), or unfavourable lifecycle stage.

3 The excluded tend to be production insufficient households marginalized from exchange networks either by choice, or unwittingly due to a lack of resources to participate.

Within exchange networks, one-way transfers from donor to recipient households may be unbalanced for long periods of time. Far from altruistic, this imbalance may be used to assert and maintain power and prestige within lineage networks, or in some cases, it may be exploited as a means of accumulation and enrichment (Torry 1987; Fafchamps 1992). In so doing, at the same time as exchange relations serve a common need for mutual insurance against risk, they may also accentuate social differentiation within the village.

Sanctions against overt displays or declarations of wealth in Bambara society may also be interpreted against this background. Households who do not find it in their capacity or interest to transfer cereal may attempt to mislead others concerning remaining cereal stocks. To avoid the 'humiliation of hunger', one household in Sèbèkoro retreated to the 
lands where unbeknownst to needy kin, lay a cache of cereal bought with migrant remittances.

In an effort to decrease the observability of their wealth, other households may shift to forms of income that are easy to dissimulate (Fafchamps 1992: 153). In the village studied, this trend was counteracted by barring those who have rejected subsistence production and participation in solidarity institutions from access to non-market transfers of labour and cereal. Despite having two eligible male workers, one newcomer household in Sebekoro refused to participate in the cibò labour group, preferring to concentrate its efforts on cash crop production. As a consequence, this household was excluded from village-level decision-making and the distribution of NGO food aid.

Most vulnerable are non-lineage households who lack sufficient resources to cultivate transfer networks with friends and lineage members through marriage or exchange (Swift 1989: 13). The isolation of these households is further exacerbated by an inability or unwillingness to participate in communal labour arrangements. Because they tend to be small in size (Lewis 1981, Richards 1986; Toulmin 1986), these households are less able divert scarce labour to communal work groups as the immediate cost to domestic agriculture is often perceived as greater than the benefits of later and less certain claims on communal labour. Even if free communal labour is available, few can afford to feed participating workers. Migrant networks may be less lucrative for similar reasons as they can ill afford to release scarce labour resources from domestic production (Toulmin 1986: 61).

In the absence of networks whereby cereal might be procured as a loan or gift during periods of shortage, excluded households are forced into volatile wagelabour and cereal markets. Even then, their relative poverty restricts access to loans and credit from market traders (Hill 1972). Subject to onerous interest rates and rainy season prices, they are compelled to repay cereal loans in cash or kind from harvest earnings. In Sèbèkoro, almost one-half of production deficit households were compelled to sell grain required for subsistence in order to cover tax, debt repayment and other social expenditures.

\section{DISCUSSION}

The apparent resilience of the so-called 'moral economy' in central Mali points to the wariness and inability of rural households to rely solely on state or market mechanisms to cope with food insecurity. Despite the existence of a country-wide early-warning system, government food aid did not reach any of the households surveyed in 1988, many of whom went hungry. While the current orthodoxy expects the market to take the place of the state, it too has a flimsy institutional foundation. Not only must farmers pay a premium for service delivery by the market, many entrepreneurs are unwilling to engage in cereal trade given supply and demand uncertainties associated with extreme variations in rainfall (Bratton 1987; Klaus 1976; Staatz et al. 1989).

In fact, the distinction between 'moral' and 'market' economies in Mali is blurred by a long history of coexistence. Commodity exchange blends with patron-client relations as local market traders provide interest-free cereal loans to reward the loyalty of rural clients. In a similar way, the volatility of cropping fortunes and need for money income has necessitated the development of broad and diverse transfer networks which encompass local reciprocity as well as wider orbits of exchange involving urban migrants, market traders and the state.

Non-market transfers occur alongside a complex of other coping strategies some of which intensify as food insecurity increases in scope and severity, and reciprocity contracts. For households with access to social networks of exchange, non-market strategies such as gift transfers, charitable labour and credit from villagecerealbanks providean important means of spreading risk. Lineage membership is an important criterion for participation in these networks. Not only may lineage households call on the assistance of immediate kin, their social and economic status facilitates the extension of networks through exogamous marriage. In this way, otherwise unviable lineage households disabled by illness or unfavorable lifecycle stage are sustained (Lewis 1981: 60).

Excluded from thesenetworks arenon-lineagehouseholds unable or unwilling to invest in the social strategies and institutions which mediate non-market exchange. Among the most vulnerable are small, asset poor households who rarely meet subsistence needs through domestic production. Without the benefit of social networks, these households are forced into volatile wage labour and cereal markets in order to survive.

Social strategies and institutions in rural Mali are not merely passive structures upon which drought and 
famine have a disruptive effect. In view of the limited competence of state and market, they represent a vital (but not exclusive) means of minimizing risk in an uncertain environment. Understanding how local systems of mutual insurance might be strengthened and extended to include the marginalized may stimulate new strategies for famine prevention.

\section{REFERENCES}

Adams, A.M., 1992, 'Seasonal food insecurity in the Sahel: nutritional, social and economic risk among Bamana agriculturalists in Mali', unpublished PhD thesis, Faculty of Medicine, University of London

Bledsoe, C.H.,Ewbank, D.C. and Isiugo-Abanihe,U.C., 1988, 'The effect of child fostering on feeding practices and access to health services in rural Sierra Leone', Social Science and Medicine Vol 27 No 6: 627-636

Brasseur, G., 1961,'Etudedegéographie régionale: le village de Tenentou (Mali)', Bulletin de l'IFAN Vol 23 No 34: 607675

Bratton, 1987, 'Drought, food and the social organization of small farmers in Zimbabwe', in M. H. Glanz (ed.) Drought and Hunger in Africa: Denying Famine a Future, Cambridge: Cambridge University Press: $323-348$

Bulletin S.A.P., 1987-90, Comité National d'actions d'urgence et de réhabilitation, Projet système d'alerte précoce, Bamako, Mali: Ministère de l'administration territoriale et du dévéloppement à la base

Chambers, R., Longhurst, R. and Pacey, P., 1981, Seasonal Dimensions to Rural Poverty, London: Francis Pinter

Dirks, R., 1980, 'Social responses during severe food shortages and famine' Current Anthropology Vol 21 No 1: 21-44

Evans-Pritchard, E.E., 1940, The Nuer, Oxford: Clarendon Press

Fafchamps, M., 1992, 'Solidarity networks in preindustrial societies: rational peasants in a moral economy', Economic Development and Cultural Change Vol 41 No 1: 147-174

Firth, R., 1959, Social Change in Tikopia, New York: Macmillan

Fortes, M., 1949, The Web of Kinship of the Tallensi, Oxford: Oxford University Press

Fortes, M. and Fortes, S.L., 1936, 'Food in the domestic economy of Tallensi', Africa Vol 9: 237-275

Fulton, D. and Toulmin, C., 1982, A Socio-Economic Study of an Agro-Pastoralist System in Central Mali, Bamako: International Livestock Centre for Africa

Goody, J. (ed.), 1958, The Developmental Cycle in Domestic Groups, Cambridge: Cambridge University Press

Hill, P., 1972, Rural Hausa: a Village and a Setting, Cambridge: Cambridge University Press
Klaus, E., 1976, Tradition and Progress in the African Village: the Non-Capitalistic Transformation of Rural Communities in Mali, London: C. Hurst and Company

Labouret, H., 1934, Les Manding et leur langues, Paris: Libra rie Larosse

Laughlin, C.D., 1974, 'Deprivation and reciprocity', Man Vol 9: 380-396

Lewis, J., 1979, 'Descendents and crops: two poles of production in a Malian peasant village', unpublished Thesis: Yale University

1981, 'Domestic labour intensity and the incorporation of Malian peasants into localized descent groups',American Ethnologist Vol 8 No 2: 53-73

Mauss, M., 1950, The Gift: The Form and Reason for Exchange in Archaic Societies, London: Routledge and Kegan Paul Plc

McNaughton, P.R., 1988, The Mande Blacksmiths: Knowledge, Power and Art in West Africa, Bloomington: Indiana University Press

Meillasoux,C., 1981,Maidens, Meal and Money: Capitalism and the Domestic Community, Cambridge: Cambridge University Press

Norman, D., 1977, 'The rationalization of inter-cropping', African Environment Vol 2 No 3: 3-21

Pales, L.C., Tassin de Saint, P.M. and Mayer, A., 1954, L'alimentation en: AOF milieux - enquetes - techniques rations, Dakar: ORANA

Paques, V., 1954, Les Bambara: monographies éthnologiques Africaines. Institute Intemational Africain, Paris: Presses Universitaires de France

Platteau, J.P., 1991, 'Traditional systems of social security and hunger insurance: past achievements and modern challenges', in E. Ahmad, J. Dreze and A. Sen (eds) Social Security in Developing Countries, Oxford:Clarendon Press, pp 112-170

Polanyi, K., 1944, The Great Transformation, New York: Holt, Rinehart and Winston

Posner, R.A., 1980,'A theory of primitive society with special reference to law', Joumal of Law and Economics Vol 23 April: 1-53

Raynault, C., 1975, 'Le cas de la region de Maradi (Niger)', in J. Copans (ed.), Secheresse et famine du Sahel, Paris: Maspero: 5-42 
Richards, P., 1985, Indigenous Agricultural Revolution: Ecology and Food Production in West Africa, London: Hutchison

1986, Coping with Hunger: Hazard and Experiment in an African Rice-Farming System, London: Allen and Unwin

Sahlins,M.D., 1965, 'On the sociology of primitive exchange', in M. Banton (ed.) The Relevance of Models for Social Anthropology, London: Tavistock Publications: 139-236

Scott, J.C., 1976, The Moral Economy of the Peasant: Rebellion and Subsistence in Southeast Asia, New Haven: Yale University Press

Sen, A., 1981,Poverty and Famines: An Essay on Entitlement and Deprivation, Oxford: Oxford University Press

Staatz, J.M., Dione, J. and Bembele, N.N., 1989, 'Cereals market liberalization in Mali', World Development Vol 17 No 5: 703-718

Swift, J., 1989, 'Why are rural people vulnerable to famine?', IDS Bulletin Vol 20 No 2: 8-15
Torry, W.I., 1987, Evolution of food rationing systems with reference to African group farms in the context of drought', in M. H. Glanz (ed.) Drought and Hunger in Africa: Denying Famine a Future, Cambridge: Cambridge University Press: 323-348

Toulmin, C., 1986, 'Access to food, dry season strategies and household size amonst the Bamara of central Mali', IDS Bulletin Vol 17 No 3: 58-66

Trimingham, J.S., 1959, Islam in West Africa, Oxford: Claredon Press

Turnball, C., 1972, The Mountain People, New York: Simon and Schuster

Watts, M., 1984, 'The demise of the moral economy: food and famine in a Sudano-Sahelian region in historical perspective', in E. Scott (ed.) Life Before the Drought, New York: Allen and Unwin: 124-148

White, B., 1980, 'Rural household studies in anthropopological perspectives' in H. Biswanger et al. (eds) Rural Household Studies in Asia, Singapore: Singapore University Press, 3-26 